\title{
NUMERICAL ANALYSIS OF BRIDGE GIRDER WITH COMPOSITE DOWEL SHEAR CONNECTION
}

\author{
Piotr LACKI ${ }^{1}$, Jacek NAWROT ${ }^{2}$ \\ Czestochowa University of Technolgy, Częstochowa, Poland
}

\begin{abstract}
The work presents a brief description of VFT-WIB ${ }^{\circledR}$ steel-concrete composite beams, examples of composite dowel shear connection shapes are presented. A steel-concrete bridge girder construction solution for the new shape of composite dowel shear connection was proposed. The geometric parameters of the steel section web cutting line are given. For the assumed cross-section dimensions, a numerical model of the girder was made. Numerical analysis was performed, the results of which were compared with the results of the analytical calculations. A program of actions aimed at further optimization of the model is presented.
\end{abstract}

Keywords: $\quad$ steel-concrete composite beams, composite dowels, VFT-WIB ${ }^{\circledR}$ beams

\section{INTRODUCTION}

Due to the continuous development of steel-concrete composite structures both in Poland [1] and abroad [6], new, innovative and more effective solutions are appearing. One sort of this type of construction is VFT-WIB ${ }^{\circledR}$ girders. Like any composite structure, they consist of steel and concrete components. The steel component comprises a T-beam formed by cutting in half a rolled I-beam, wherein the cutting line extends into the middle of the web height. Thanks to that, by cutting one I-beam, we obtain elements for two girders. The shape of the cutting line is chosen in such a way as to ensure connection of the T-beam with

\footnotetext{
${ }^{1}$ Corresponding author: Czestochowa University of Technology, Faculty of Civil Engineering, Dabrowskiego st 69, 42-201 Czestochowa, Poland, e-mail: piotr@lacki.com.pl, tel+48343250965

${ }^{2}$ Corresponding author: Czestochowa University of Technology, Faculty of Civil Engineering, Dabrowskiego st 69, 42-201 Czestochowa, Poland, e-mail: jnawrot@bud.pcz.czest.pl, tel.+48343250965
} 
the reinforced concrete slab without the need for any fasteners. The reinforced concrete slab is partly prefabricated, acting as formwork for monolithic part. This solution reduces the weight of prefabricated composite beams and improves the economics of transport and assembly. At the same time, the prefabricated part of the slab eliminates the need for additional formwork during the concreting of its monolithic part. In the case of new construction solutions, preliminary assessment of their correctness can be made using numerical analysis. In the article an attempt is made to create a numerical model of a VFT-WIB ${ }^{\circledR}$ steel-concrete composite girder with an innovative composite dowel shear connection (for a new shape of web cutting line) to perform a preliminary of the correctness of the adopted structural design.

\section{GENERAL CHARACTERISTICS OF VFT-WIB ${ }^{\circledR}$ GIRDERS}

The precursor of VFT-WIB ${ }^{\circledR}$ composite girders were VFT ${ }^{\circledR}$ girders used in bridges of an average span length [5]. Their cross-section is formed by a welded steel I-beam whose upper flange is connected to the prefabricated reinforced concrete slab by means of Nelson studs (Fig. 1). The thickness of the prefabricated part of the slab is in the range of $10-12 \mathrm{~cm}$ and constitutes the formwork for the monolithic platform slab [4].

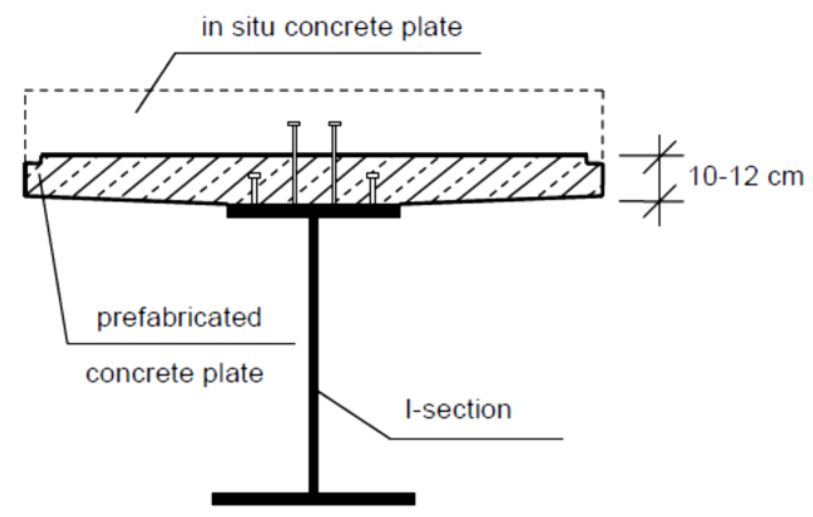

Fig. 1. VFT girder

The next step in the development of the VFT® girder system was to replace the welded steel sheet with a hot rolled steel I-beam, cut into two halves - thanks to that, the elements for two girders were obtained from one section. Cutting occurs at half the web height and its shape allows the steel T-cross-section to be joined to the concrete slab without the use of fasteners. The reinforced concrete slab can be shaped in such a way that the beam web is partially or completely concreted (Fig. 2). 


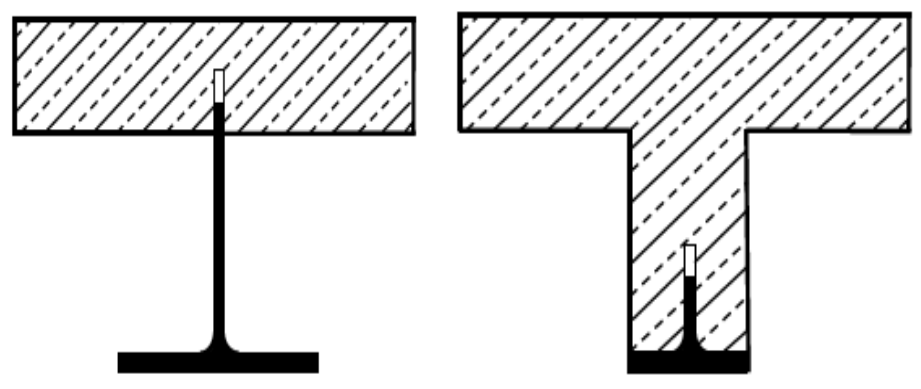

Fig. 2.VFT-WIB girders

The use of rolled I-beams (instead of welded plates) and the elimination of Nelson studs favourably affect the economics of producing VFT-WIB ${ }^{\circledR}$ girders (Fig. 2), and due to the absence of welds, greater fatigue resistance of the lower flange is achieved with respect to welded sheets.

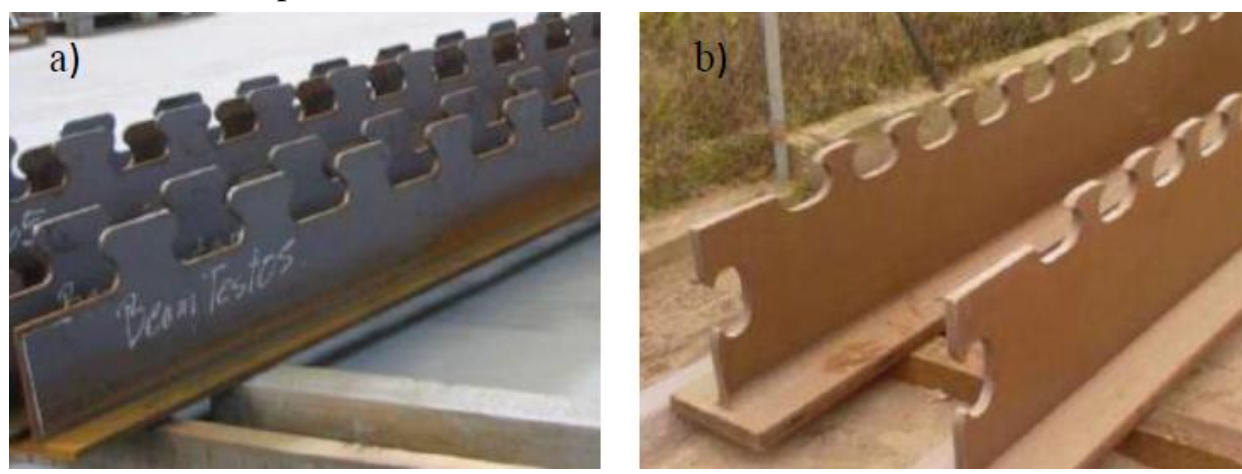

Fig. 3. Shapes of composite dowel shear connections: a) PZ, b) MCL [3]

An important issue affecting the quality of the connection is proper shaping of the web cuts so as to obtain the required load capacity of the slab and steel T-beam connection. For economic reasons (material consumption, waste limitation), it is assumed that the shape of the cut should be such that two symmetric elements of one section are obtained. The resulting shear connections are treated as continuous connectors that convey the longitudinal shear force between the concrete slab and the steel profile and are termed composite dowel shear connections. The shape of a single "tooth" should be symmetrical in order to achieve uniform gravity of the connection, irrespective of the direction of the longitudinal shear force. Examples of such solutions are PZ and MCL shapes (Fig. 3 ). These solutions are constantly being developed for typical VFT-WIB ${ }^{\circledR}$ girders and welded plate girders that are the connection components of bridge girders [2]. 


\section{GOAL AND SCOPE OF WORK}

The aim of the work was to perform a numerical analysis of a bridge girder with a composite dowel shear connection. The scope of the work included the calculation of the bending stress values in a cross-section of a beam and the maximum displacement. Analytical calculations were performed using the crosssection replacement method. Results of the numerical analysis were compared to the results from the analytical calculations.

It was assumed that the girder would have a span of $15 \mathrm{~m}$ in the support axis, its cross-section would be created by a T-beam, obtained by cutting in two halves an HEB 900 I-beam as well as a $25 \mathrm{~cm}$ thick reinforced concrete slab. The shape of the notches to ensure that the steel element is joined to the reinforced concrete slab is selected in such a way as to ensure sufficient anchorage of the web in the concrete while minimizing the amount of waste (Fig. 4).

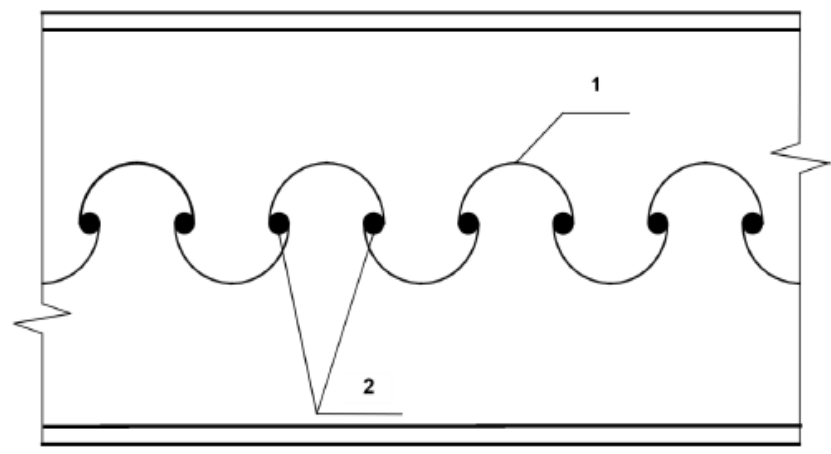

Fig. 4. Shape of web cut: 1 - cutting line, 2 - waste

The dimensions of the dowels and the radii of curvatures should be selected so as to ensure correct alignment of the steel element with the concrete slab and to maintain minimum values of concrete cover for the reinforcement bars. Taking into account the above factors, the geometry shown in Fig. 5 is proposed, where cut-out radii $\mathrm{R} 1=60 \mathrm{~mm}, \mathrm{R} 2=10 \mathrm{~mm}$.

The remaining parameters of the cross-section of the analysed bridge girder are as follows:

- steel profile $1 / 2$ HEB 900;

- structural steel S 235;

- reinforced concrete slab $25 \mathrm{~cm}$ thick;

- width of concrete flange $100 \mathrm{~cm}$;

- concrete C 30/37;

- longitudinal reinforcement $\varnothing 12$ (arrangement according to Fig. 6);

- transverse reinforcement Ø 12 spacing every $200 \mathrm{~mm}$;

- reinforcing steel RB500W. 


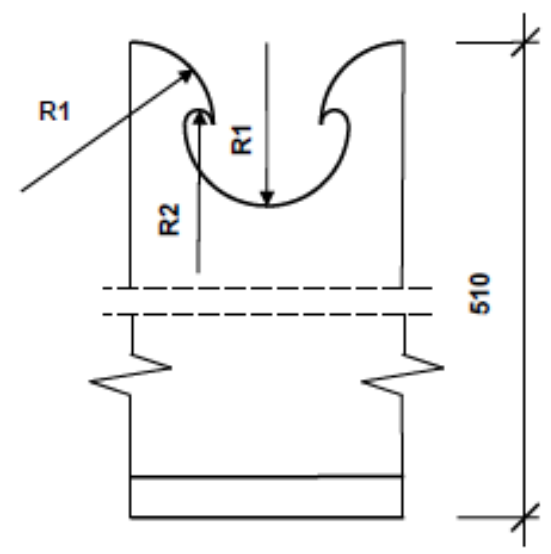

Fig. 5. Geometry of web cuts for repetitive fragment of steel T-beam

A scheme of freely supported beams with a span of $15 \mathrm{~m}$ in the axis supports was assumed. For the purposes of calculation, the following characteristic loads were adopted:

- weight of steel element: $1.45 \mathrm{kN} / \mathrm{m}$;

- $\quad$ weight of reinforced concrete slab: $6.25 \mathrm{kN} / \mathrm{m}^{2}$;

- $\quad$ weight of platform slab with finishing layers: $7.50 \mathrm{kN} / \mathrm{m}^{2}$;

- usable load: $10 \mathrm{kN} / \mathrm{m}^{2}$.

The cross-section of the analysed girder along with the location of reinforcement is shown in Fig. 6.

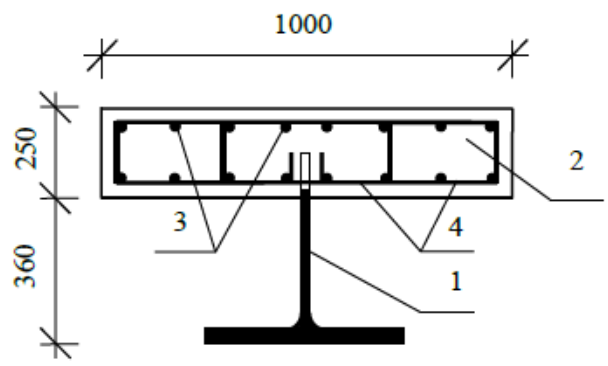

Fig. 6. Cross-section of analysed beam 1- 1/2 HEB 900, 2 - concrete slab, 3- longitudinal reinforcement $\varnothing 12,4$ - transverse reinforcement $\varnothing 12$, spaced every $200 \mathrm{~mm}$ connection

\section{NUMERICAL MODEL OF GIRDER}

The calculations were performed by means of the ADINA program, using the finite element method. The proposed numerical model consists of 1170 3D solids 
with 27 nodes for the steel sections, 7860 3D solids with 8 nodes for the concrete slabs, 3632 general truss elements for the reinforcement rods $\varnothing 12,829$ general truss elements for the reinforcement bars 2 x $\varnothing 12,4$ 3D solids with 27 nodes for the supports. The total number of generated finite elements is 13495 giving 43848 nodes of the FEM grid. The view of the accepted model along with the assumed boundary conditions and applied load is shown in Fig. 7.

For the steel section material, an elastic-plastic material model for structural steel S235 was adopted with the following parameters:

- density $\rho=7850 \mathrm{~kg} / \mathrm{m}^{3}$;

- Poisson's ratio $v=0.3$;

- Young's modulus $210 \mathrm{GPa}$;

- yield limit $\mathrm{f}_{\mathrm{y}}=235 \mathrm{MPa}$;

- ultimate tensile strength $\mathrm{f}_{\mathrm{u}}=360 \mathrm{MPa}$;

- relative elongation $\mathrm{A}_{5}=21$ [\%].

For the reinforcement bar material, the elastic-plastic material model for RB500W steel was adopted with the following parameters :

- density $\rho=7850 \mathrm{~kg} / \mathrm{m}^{3}$;

- Poisson's ratio $v=0.3$;

- Young's modulus $205 \mathrm{GPa}$;

- $\quad$ yield limit $\mathrm{f}_{\mathrm{y}}=500 \mathrm{MPa}$;

- ultimate tensile strength $\mathrm{f}_{\mathrm{u}}=550 \mathrm{MPa}$;

- relative elongation $\mathrm{A}_{5}=7$ [\%].

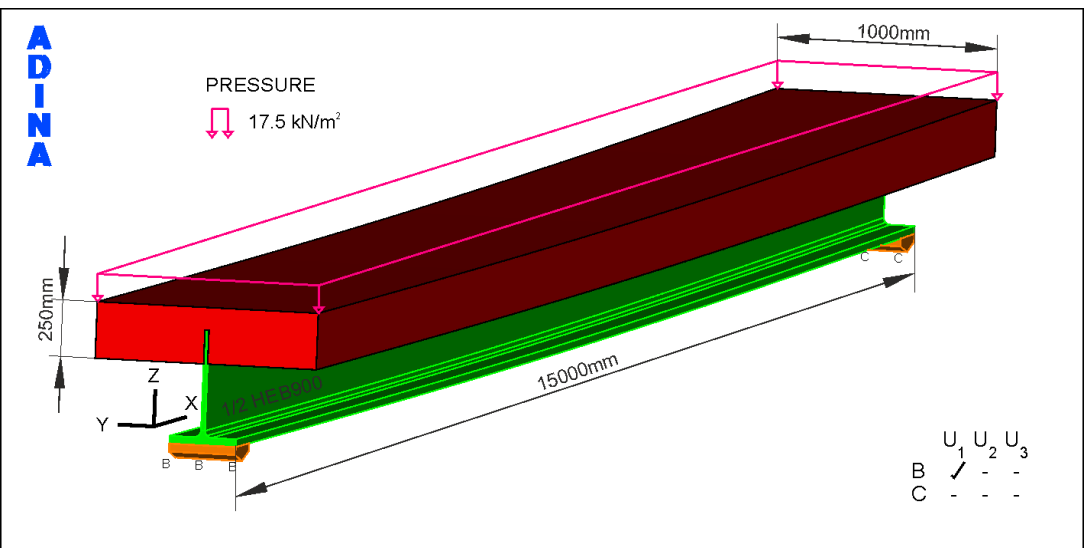

Fig. 7. View of numerical model of girder with assumed load and boundary conditions

For the $\mathrm{C} 30 / 37$ concrete material, a model conforming to the ADINA Theory and Modelling Guide; Report ARD 13-8. ADINA R \& D, Inc. was adopted with the following parameters:

- density $\rho=2500 \mathrm{~kg} / \mathrm{m}^{3}$;

- secant modulus of elasticity of concrete $\mathrm{E}_{\mathrm{cm}}=32 \mathrm{GPa}$; 
- average value of axial tensile strength of concrete $\mathrm{f}_{\mathrm{ctm}}=2.9 \mathrm{MPa}$;

- characteristic cylindrical compressive strength of concrete at 28 days $\mathrm{f}_{\mathrm{cm}}=38$ $\mathrm{MPa}$;

- smallest deformation at which compressive strength is attained $\varepsilon_{\mathrm{c} 1}=2.2 \%$;

- ultimate compressive strength of concrete $\mathrm{f}_{\mathrm{ck}}=30 \mathrm{MPa}$;

- boundary deformation $\varepsilon_{\mathrm{cu} 2}=3.5 \%$.

The main reinforcement system in the concrete slab of the analysed girder is shown in Fig. 8.

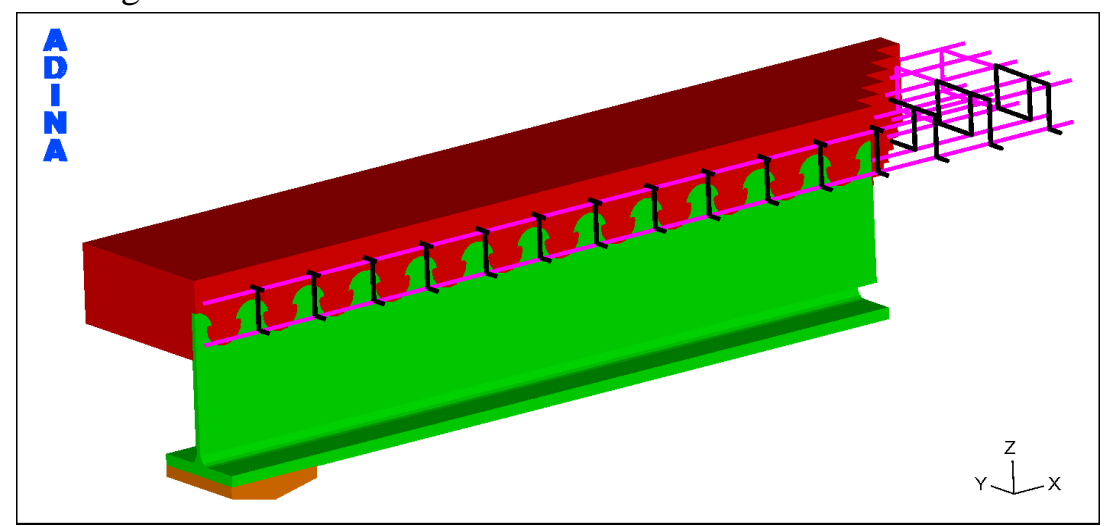

Fig. 8. Sectional view of girder with reinforcement distribution of $200 \mathrm{~mm}$

\section{RESULTS ANALYSIS}

Based on the conducted numerical calculations, the maximum bending stresses in the steel section (Fig. 9) and the concrete slab (Fig. 10) were determined.

Due to the adopted static pattern of the girder (freely supported beam), the most strained cross-section will be the mid-section. The maximum tensile stresses in this section in the steel section flange amount to $109 \mathrm{MPa}$. The upper part of the web within the notches (dowels) is compressed and the maximum stress value at this point amounts to $39.19 \mathrm{MPa}$. The compressive stresses on the top edge of the concrete slab amount to $10.76 \mathrm{MPa}$ and the maximum compressive stresses in the concrete occur within the steel "tooth" contact with the concrete and amount to 18.58 MPa. The size of girder displacement determined on the basis of numerical calculations amounted to $33.23 \mathrm{~mm}$ for the $\mathrm{Z}$ direction and $5.88 \mathrm{~mm}$ for the $\mathrm{X}$ direction (Fig. 11). 


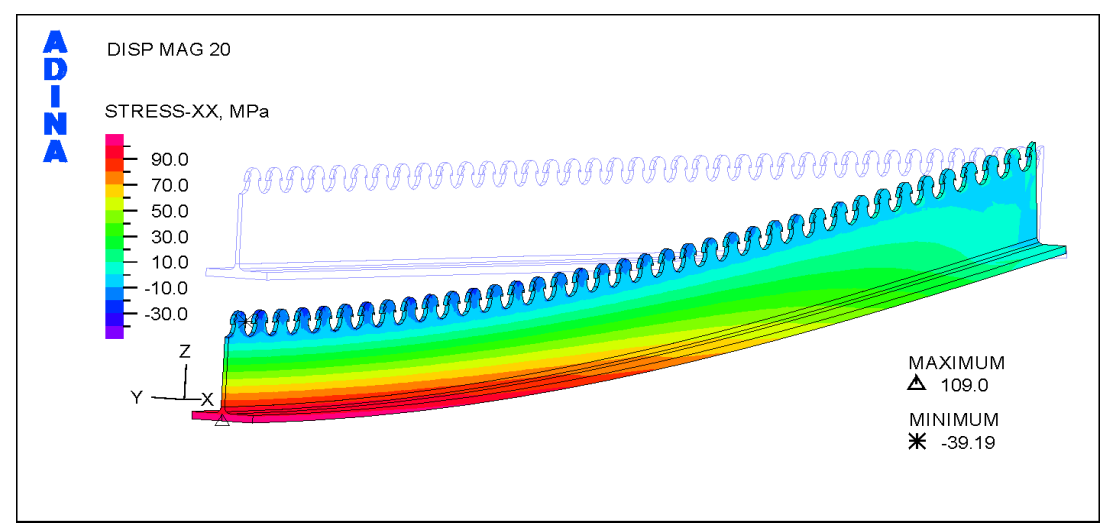

Fig. 9. Normal stress in steel section - view of half length of girder

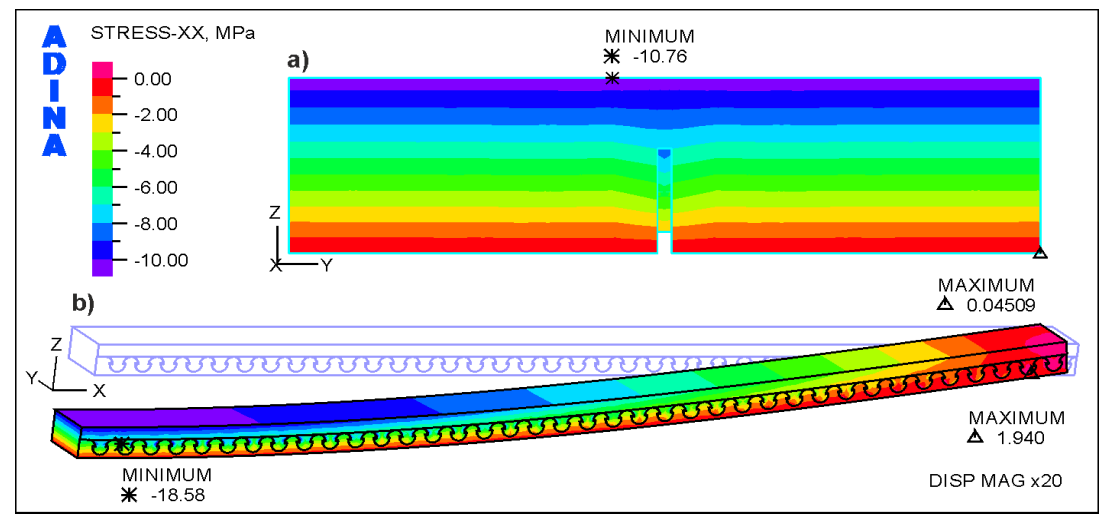

Fig. 10. Normal stress in concrete slab: a) transversal cross-section, b) longitudinal cross-section for half length of girder

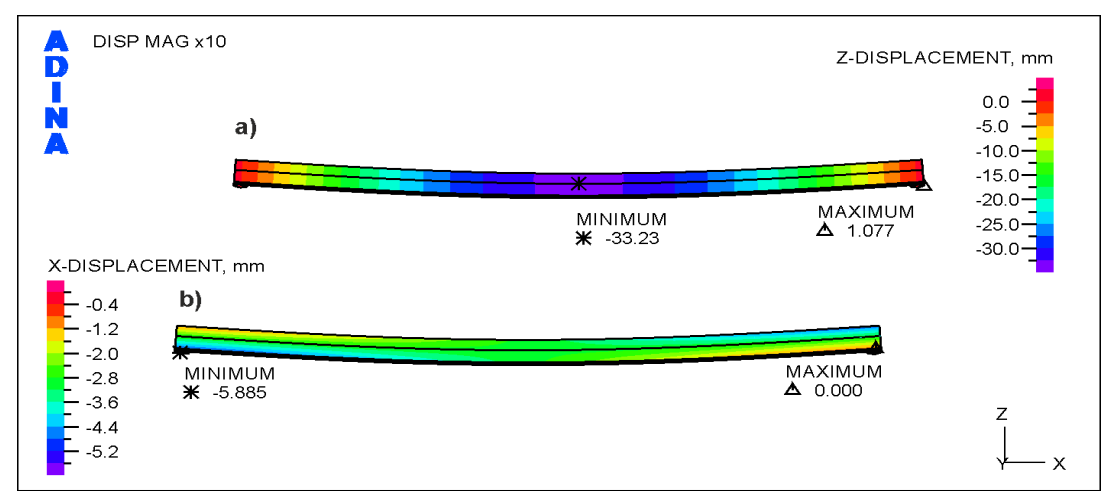

Fig. 11. Displacement of girder numerical model: a) in $\mathrm{Z}$ direction, b) in $\mathrm{X}$ direction

In order to validate the proposed numerical model, analytical calculations were performed (using the cross-section replacement method) on the basis of which the 
values of bending stress in a cross-section of the beam and the maximum deflection were determined. The value of maximum tensile stress in the steel section amounted to $112.48 \mathrm{MPa}$ and compressive stress in the concrete slab $11.79 \mathrm{MPa}$ (Fig. 12).

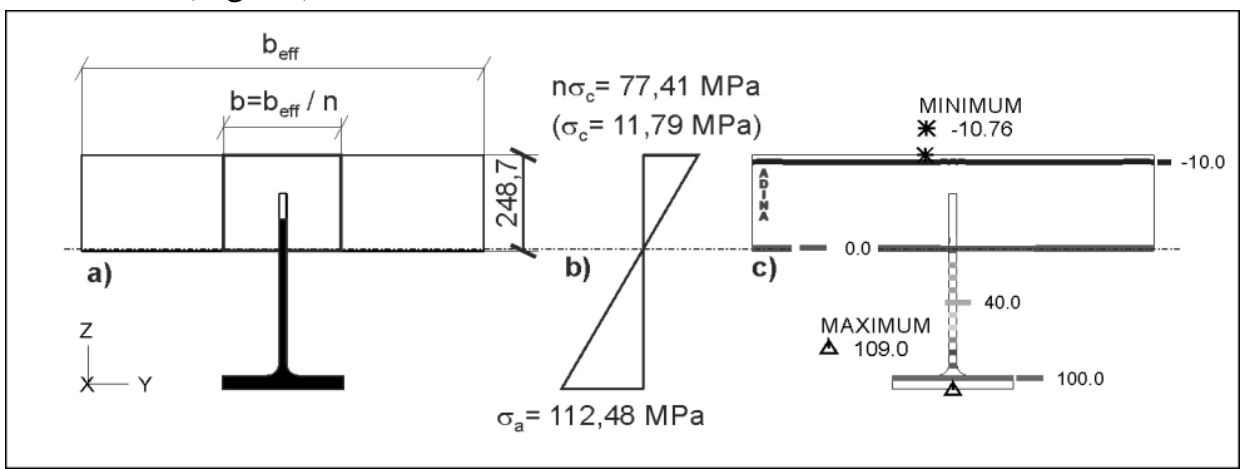

Fig. 12. Distribution of bending stress in connected section: a) computational crosssection of girder, b) distribution of bending stresses determined analytically,

c) distribution of stresses in numerical model

The deflection in the centre of the girder span is equal to $34.74 \mathrm{~mm}$. The obtained results of the analytical calculations coincide with the results of the numerical calculations - the differences between the individual values (for the numerical and analytical calculations) oscillate within the limits of $3.2-9.6 \%$ and the position of the neutral axis of the connected section in both cases is identical.

\section{CONCLUSIONS}

The proposed numerical model appropriately reflects the work of the analysed steel-concrete composite girder. The maximum deflection and bending stress values in the most strained cross-section, determined by the analytical method, coincide with the results of the numerical calculations. Slight discrepancies (3.2 $\%$ for deflection and $9.6 \%$ for bending stress) between the analytical and numerical approaches result from the approximate nature of the analytical method. Due to the satisfactory results of the performed calculations, the presented numerical model can be further developed and refined, in particular in determining the bearing capacities of the connection for the proposed shape of the web cutting line. 


\section{REFERENCES}

1. Biliński T., Kmita J.: Dorobek nauki polskiej w zakresie konstrukcji zespolonych, Zielona Góra, Oficyna wydawnicza Uniwersytetu Zielonogórskiego 2009.

2. Dudziński W., Pękalski G., Harnatkiewicz P., Kopczyński A., Lorenc W., Kożuch M., Rowiński S.: Study on fatigue cracks in steel-concrete shear connection with composite dowels, Archives of Civil and Mechanical Engineering, 11, 4, (2011) 839-858.

3. Kołakowski T., Kosecki W., Lorenc W., Rabiega J., Seidl G.: Prefabrykowane dźwigary zespolone stalowo-betonowe VFT-WIB do budowy przęset mostów drogowych i kolejowych, Inżynieria i Budownictwo, nr 7-8, (2011) 379-382.

4. Lorenc W., Kołakowski T., Kosecki W., Seidl G.: Prefabrykowane dźwigary zespolone z innowacyjnym połaczeniem stali i betonu, NBI 6 (21) 2008.

5. Lorenc W.: Boundary Approach in Shape Study of Composite Dowel Shear Connector, Archives od Civil and Mechanical Engineering, 9,4 (2009) 55-66.

6. Seidl G., Zanon R., Lorenc W., Franssen J., Fohn T.: Wytyczne do projektowania. Prefabrykowane trwale belki zespolone $z$ innowacyjnym połączeniem ścinanym, Dolnośląskie Wydawnictwo Edukacyjne 2012.

\section{ANALIZA NUMERYCZNA DŹWIGARA MOSTOWEGO Z ZESPOLENIEM TYPU "COMPISITE DOWELS"}

\section{Streszczenie}

W pracy przedstawiono krótką charakterystykę stalowo-betonowych belek zespolonych typu VFT-WIB®, zaprezentowano przykładowe kształty zespolenia typu "composite dowels". Zaproponowano rozwiązanie konstrukcyjne stalowo-betonowego dźwigara mostowego dla nowego kształtu zespolenia typu "composite dowels". Założono, że dźwigar będzie miał rozpiętość w osi podpór $15 \mathrm{~m}$, jego przekrój będzie tworzył teownik stalowy uzyskany $\mathrm{z}$ rozcięcia na dwie połowy dwuteownika HEB 900 oraz płyta żelbetowa grubości $25 \mathrm{~cm}$. Podano parametry geometryczne linii cięcia środnika kształtownika stalowego. Przyjęto schemat statyczny dźwigara w postaci belki swobodnie podpartej obciążonej obciążeniem równomiernie rozłożonym uwzględniającym ciężar własny konstrukcji oraz obciążenie użytkowe. Dla założonych wymiarów przekroju poprzecznego wykonano model numeryczny dźwigara przy użyciu programu ADINA wykorzystującego Metodę Elementów Skończonych. Przeprowadzono analizę numeryczną na podstawie, której określono wartości naprężeń normalnych w kształtowniku stalowym oraz w płycie betonowej a także ugięcie dźwigara. Wyniki 
NUMERICAL ANALYSIS OF BRIDGE GIRDER WITH COMPOSITE DOWEL SHEAR 65 CONNECTION

obliczeń numerycznych porównano $\mathrm{z}$ wynikami przeprowadzonych obliczeń analitycznych. Wykazano zbieżność między wynikami numerycznymi i analitycznymi.

Słowa kluczowe: stalowo-betonowe belki zespolone, zespolenie composite dowels, belki VFT-WIB ${ }^{\circledR}$

Editor received the manuscript: 13.10 .2017 